\title{
Benzene and 2-ethyl-phthalate induce proliferation in normal rat pituitary cells
}

\author{
Laura Tapella ${ }^{1} \cdot$ Antonella Sesta $^{2} \cdot$ Maria Francesca Cassarino $^{2}$. \\ Valentina Zunino $^{3}$ - Maria Graziella Catalano ${ }^{4}$. \\ Francesca Pecori Giraldi ${ }^{1,2}$ (D)
}

Published online: 16 November 2016

(c) The Author(s) 2016. This article is published with open access at Springerlink.com

\begin{abstract}
Purpose Endocrine disruptors are known to modulate a variety of endocrine functions and increase the risk for neoplasia. Epidemiological data reported increased prevalence of pituitary tumors in high industrial areas while genotyping studies showed that mutations in the aryl hydrocarbon receptor (AhR) interacting protein (AIP) chaperone to the dioxin ligand $\mathrm{AhR}$ - gene are linked to predisposition to pituitary tumor development. Aim of the present study was to establish whether endocrine pollutants can induce cell proliferation in normal rat pituitary cells. Methods Pituitary primary cultures were incubated with 250, 650 and $1250 \mathrm{pM}$ benzene or 2-ethyl-phthalate for up to $96 \mathrm{~h}$ and viability, energy content and cell proliferation assessed. Expression of pituitary tumor transforming gene $(P T T G)$, cyclin D1 (Ccndl), AhR and AIP was quantified by RT-qPCR.
\end{abstract}

Electronic supplementary material The online version of this article (doi:10.1007/s11102-016-0777-3) contains supplementary material, which is available to authorized users.

Francesca Pecori Giraldi

francesca.pecorigiraldi@unimi.it

1 Department of Clinical Sciences and Community Health, University of Milan, Milan, Italy

2 Neuroendocrinology Research Laboratory, Istituto Auxologico Italiano, Via Zucchi 18, 20095 Cusano Milanino, MI, Italy

3 Unit of Oncological Endocrinology, Azienda Ospedaliera Universitaria Città della Salute e della Scienza di Torino, Turin, Italy

4 Department of Medical Sciences, University of Turin, Turin, Italy
Results Incubation with benzene or 2-ethyl-phthalate increased viability and energy content in pituitary cells. The endocrine disruptors also increased cell proliferation as well as $C c n d l$ and $P T T G$ expression. Increased $A h R$ and $A I P$ expression was observed after incubation with the two pollutants.

Conclusions Our findings indicate that benzene and 2-ethyl-phthalate activate AhR/AIP expression and stimulate proliferation in normal rat pituitary cells. This study is the first demonstration that pollutants can induce normal pituitary cells to proliferate and provides a link between epidemiological and genomic findings in pituitary tumors.

Keywords Endocrine disruptor - Pituitary adenoma Proliferation - Aryl hydrocarbon receptor (AhR) - Aryl hydrocarbon receptor-interacting protein (AIP)

\section{Introduction}

Endocrine disruptors are widely distributed chemical pollutants known to affect endocrine functions [1,2], in particular reproduction and development. Indeed, it is known since the early 1970s that breeding patterns, sex of offspring and fetal maturation are variably affected by endocrine toxicants $[3,4]$ as is hormonal production $[2,5]$.

More recently, the carcinogenic potential of endocrine disruptors has become a major research focus following epidemiological data showing an association between endocrine disruptor exposure and breast, prostate, testis and thyroid neoplasia [6-10]. In support of this evidence, in vitro studies showed that endocrine disruptors induce cell cycle deregulation, death and proliferation in breast and ovarian cancer cell lines [11-13]. Similar growthpromoting effects have also been reported for estrogensensitive pituitary adenoma cell lines, e.g. MtT/E2 [14, 15], 
$\mathrm{GH}_{3}[16,17]$, suggesting that endocrine disruptors may be linked to pituitary tumor development. Further, in vivo models revealed a higher incidence of pituitary adenomas in rats treated with a mixture of endocrine disruptors [18]. In humans, epidemiological studies showed an increased prevalence of growth hormone $(\mathrm{GH})$-secreting pituitary tumors in high industrial density areas [19] and, possibly, higher incidence of pituitary neoplasia following the accidental spillage of dioxin [20]. An additional link between endocrine disruptors and pituitary tumorigenesis was provided by the discovery of mutations in the aryl hydrocarbon receptor interacting protein $(A I P)$ gene in patients with pituitary tumors [21], as the aryl hydrocarbon receptor (AhR) is well-known to bind toxins and phytochemicals [22]. Indeed, the AhR pathway is called into play by several endocrine disruptors [23], both in the pituitary and in other tissues [24, 25].

Given this evidence, we decided to study whether endocrine disruptors affect normal rat pituitaries in vitro. Our findings indicate that long-term incubation with benzene and 2-ethyl-phthalate increases cell viability, energy content and proliferation in normal rat pituitary cells. Further, we observed an increase in genes associated with cell cycle progression and pituitary tumorigenesis as well as in $A h R$ and $A I P$ expression. Taken together, our findings show for the first time that endocrine pollutants can induce proliferation in normal pituitary cells and support the contention that endocrine disruptors play a role in pituitary tumorigenesis.

\section{Materials and methods}

\section{Pituitary primary cultures}

Rat anterior pituitaries were dissected from adult male Sprague-Dawley rats, sacrificed in accordance with animal care guidelines (National Institutes of Health, Office of Animal Cure and Use). The study was approved by the Ethical Committee of the Grant Coordinating Institution, i.e. University of Messina, Italy. Pituitaries were cultured using our usual protocol [26, 27]. Briefly, pituitaries were trypsin-digested and dispersed cells plated at 50,000 cells/ well in 96 multi-well plates for cell assays and at 50,000 cells/well in 24 multi-well plates for RT-qPCR. Wells were incubated in Dulbecco's modified medium (DMEM), 10\% fetal bovine serum (FBS), antibiotics for 3-4 days (Sigma, Saint Louis MO, USA) prior to experimental procedures.

\section{Treatments}

After 3-4 days attachment, cells were washed for $1 \mathrm{~h}$ in Dulbecco's modified Eagle medium (DMEM) and $0.1 \%$ bovine serum albumin (BSA) then treated with 250, 650, 1250 pM benzene (Sigma, Saint Louis MO, USA) or bis(2-ethylhexyl)-phthalate (2-ethyl-phthalate; Sigma, Saint Louis MO, USA) for 3, 24 or $96 \mathrm{~h}$. Wells were examined by light microscope prior and at the end of incubations in order to exclude fibroblast contamination; experience over the past 20 years showed that contamination with fibroblasts or stromal cells does not constitute a problem with the current cell dispersion protocol. Incubation with $250 \mu \mathrm{g} / \mathrm{ml}$ cycloheximide (CHX) (Sigma, Saint Louis MO, USA) served as representative control for cytotoxicity given that high doses of the protein synthesis inhibitor have been shown to be cytotoxic [28, 29]; wells incubated with DMEM $+0.1 \%$ BSA represented untreated control. Treatments were repeated in four separate experiments on quadruplicate wells.

\section{Cell assays}

Metabolic cell energy content was measured by ATP lite (Perkin Elmer, Waltham MA, USA) according to the manufacturer's instructions. Wells were incubated in ATPlite assay reagent at room temperature and luminescence assessed after $10 \mathrm{~min}$.

Cell viability was measured by methylthiotetrazole (MTT) assay (Sigma, Saint Louis MO, USA). MTT was added to wells and cells incubated at $37{ }^{\circ} \mathrm{C}$ for $3 \mathrm{~h}$. Medium was subsequently discarded and cells dissolved in 1:25 $1 \mathrm{~N} \mathrm{HCl} / 100 \%$ propanol. Absorbance was read at $540 \mathrm{~nm}$.

Apoptosis was tested by Caspase Glo 3-7 assay (Promega, Madison WI, USA). Wells were incubated in Caspase 3-7 reagent at room temperature and luminescence assessed after $30 \mathrm{~min}$.

Proliferation was assessed by 5-bromo-2'-deoxyuridine labeling (BrdU-labeling; Roche, Mannheim, Germany). Cells were incubated with BrdU-labeling reagent for $16 \mathrm{~h}$, denatured then treated with anti-BrdU-POD antibody for $120 \mathrm{~min}$. Substrate reaction solution was added and reaction stopped after 30 min with $1 \mathrm{M} \mathrm{H}_{2} \mathrm{SO}_{4}$. Colorimetric signal was measured at $450 \mathrm{nM}$.

\section{RNA extraction and RT-qPCR}

RNA was extracted from pituitary primary cultures with Pure link RNA mini Kit (Life Technologies, Carlsbad CA, USA) and reverse-transcribed with SuperScriptR VILO ${ }^{\mathrm{TM}}$ cDNA Synthesis Kit (Invitrogen Life Technologies, Carlsbad CA, USA). Quantitative Real-Time PCR (qRTPCR) for Cyclin D (Ccndl) and pituitary transforming gene 1 (Pttgl) was performed using Platinum Quantitative PCR Supermix-UDG with premixed ROX Taqman assay (Applied Biosystem, Foster City CA, USA) for the detection of Ccnd1 probe Rn00432360_m1 and Pttgl probe 
Rn00574373_m1 with hypoxanthine-guanine phosphoribosyltransferase (Hprt1; probe Rn01527840_m1) as endogenous control on a 7900 HT sequence Detection System (Applied Biosystem, Foster City CA, USA). For $A h R$ and $A I P$ expression, primers were designed using Beacon Designer 5.0 software (see Online Resource ESM1.pdf) and qRT-PCR performed using BioRad MiIQ Detection System (BioRad Laboratories, Hercules CA, USA) with SYBR green fluorophore. A melting curve analysis was performed following every run to ensure a single amplified product. Basal expression data $\left(2^{-\Delta \mathrm{Ct}}\right)$ was calculated and normalized to house-keeping genes (Online Resource ESM1.pdf); expression after treatment was analyzed as $2^{-\Delta \Delta C t}$ and expressed in fold increase.

\section{Statistical analysis}

Kruskal-Wallis test was used for comparisons between treatments (Statview 5.0, Cary NC, USA) and $p<0.05$ considered statistically significant. Treatment values are given relative to control and expressed as mean \pm S.E.M.

\section{Results}

\section{Exposure to benzene and 2-ethyl-phthalate modulates cell metabolism, viability and proliferation}

Short-term incubation, i.e. $3 \mathrm{~h}$, with benzene and 2-ethylphthalate did not affect cell metabolism, cell viability or apoptosis in rat anterior pituitary primary cultures (see Online Resource ESM2.pdf). Conversely, 24-h incubation with benzene and 2-ethyl-phthalate decreased ATP levels (Fig. 1a), attesting to decreased intracellular energy at this time point. This was not associated with cell death, as no induction of apoptosis could be observed (Fig. 1c). On the other hand, cell viability at 24-h exhibited a slight, not significant, increase (Fig. 1b).

Given these results, we tested the effect of prolonged, e.g. $96 \mathrm{~h}$, incubation on rat anterior pituitary primary cultures and observed an increase in cell energy content (Fig. 2a) as well as increased cell viability (Fig. 2b). We therefore decided to assess proliferation by Brd-U incorporation and Cyclin D1 expression, a marker of cell cycle progression. The percentage of Brd-U positive cells was increased in wells treated with benzene or 2-ethyl-phthalate compared to control wells (Fig. 3a) as was Ccndl expression (Fig. 3b), attesting to increased proliferation of rat anterior pituitary cells after 96-h incubation. In view of these effects, we evaluated expression of pituitary tumor transforming gene (PTTG), a protooncogene implicated in pituitary tumorigenesis [30], and, indeed, could observe an increase in Pttgl expression in wells treated with benzene and 2-ethyl-phthalate (Fig. 3c). As expected, cyclohexamide reduced cell metabolism, viability and proliferation and induced cell apoptosis (Figs. 2, 3).

\section{Exposure to benzene and 2-ethyl-phthalate increases AhR/AIP expression}

Given the role of AhR as a mediator of endocrine disruptors [23] and of AIP, its chaperone protein, in pituitary tumorigenesis [21] we decided to study whether incubation with benzene or 2-ethyl-phthalate affects expression of either gene. No effect of the two endocrine disruptors were observed after $3 \mathrm{~h}$ whereas a clear-cut increase in both AhrR and AIP expression was apparent after 24- and 96-h incubation (Fig. 4).

\section{Discussion}

Our results show that benzene and 2-ethyl-phthalate stimulate rat anterior pituitary cell proliferation, an important finding given the increasing evidence of endocrine-disruptor induced tumorigenesis [3]. In fact, although endocrine disruptors were initially discovered due their adverse effect on reproduction and fetal development, subsequent studies demonstrated a role in an variety of endocrine disorders and, eventually, endocrine-related cancers [4, 31]. The mechanisms underlying endocrine disruptorinduced carcinogenesis are varied and as yet not fully understood but appear to comprise receptor agonism or antagonism, activation of oncogenes and/or repression of tumor suppressor genes, changes in intracellular signaling pathways and DNA methylation patterns. These effects are associated with alterations ranging from hyperplasia to carcinoma [32-34], increased risk of cancer and, ultimately, increased cancer-related mortality [3, 10].

Pituitary tumors are common intracranial neoplasias with site-related symptoms and systemic morbidity due to hormonal excess. Most are sporadic, slow-growing and diagnosed in middle-aged to older individuals [35]. Epidemiological studies are few but recent reports of increased prevalence of pituitary adenomas in high industrialized areas [19] and, possibly, after toxic spillage [20] suggested a link to environmental causes.

Experimental data provided support for this association as endocrine pollutants have been shown to exert several effects in cell lines derived from rat pituitary neoplasms, most notably estrogen-sensitive somatotropes, i.e. $\mathrm{GH}_{3}$, and mammosomatotropes, i.e. MtT/E-2. Bisphenol A, genistein, o, $\mathrm{p}^{\prime}$-DDT, cadmium and endosulfan have all been shown to increase proliferation in either cell line [14-17, 36]. Further, increased GH and prolactin synthesis 
Fig. 1 Cell energy content (a), viability (b) and apoptosis (c) in rat anterior pituitary primary $1250 \mathrm{pM}$ benzene (Ben, striped bars) or bis-(2-ethylhexyl)phthalate (2-ET, grey bars), $250 \mu \mathrm{g} / \mathrm{ml}$ of cycloheximide (CHX, black bar) for $24 \mathrm{~h}$. White bars represent control wells treated with plain medium (Ctrl). Data were normalized to control values and expressed as percentage of control; bars represent mean \pm SEM from four separate experiments cultures treated with 250,650 ,
Fig. 2 Cell energy content (a), viability (b) and apoptosis (c) in rat anterior pituitary primary cultures treated with 250,650 , $1250 \mathrm{pM}$ benzene (Ben, striped bars) or 2-ethyl-phthalate (2cycloheximide (CHX, black bar) for $96 \mathrm{~h}$. White bars represent control wells treated with plain medium $(\mathrm{Ctrl})$. Data were normalized to control values and expressed as percentage of control; bars represent mean \pm SEM from four separate experiments $\mathrm{ET}$, grey bars), $250 \mu \mathrm{g} / \mathrm{ml}$ of
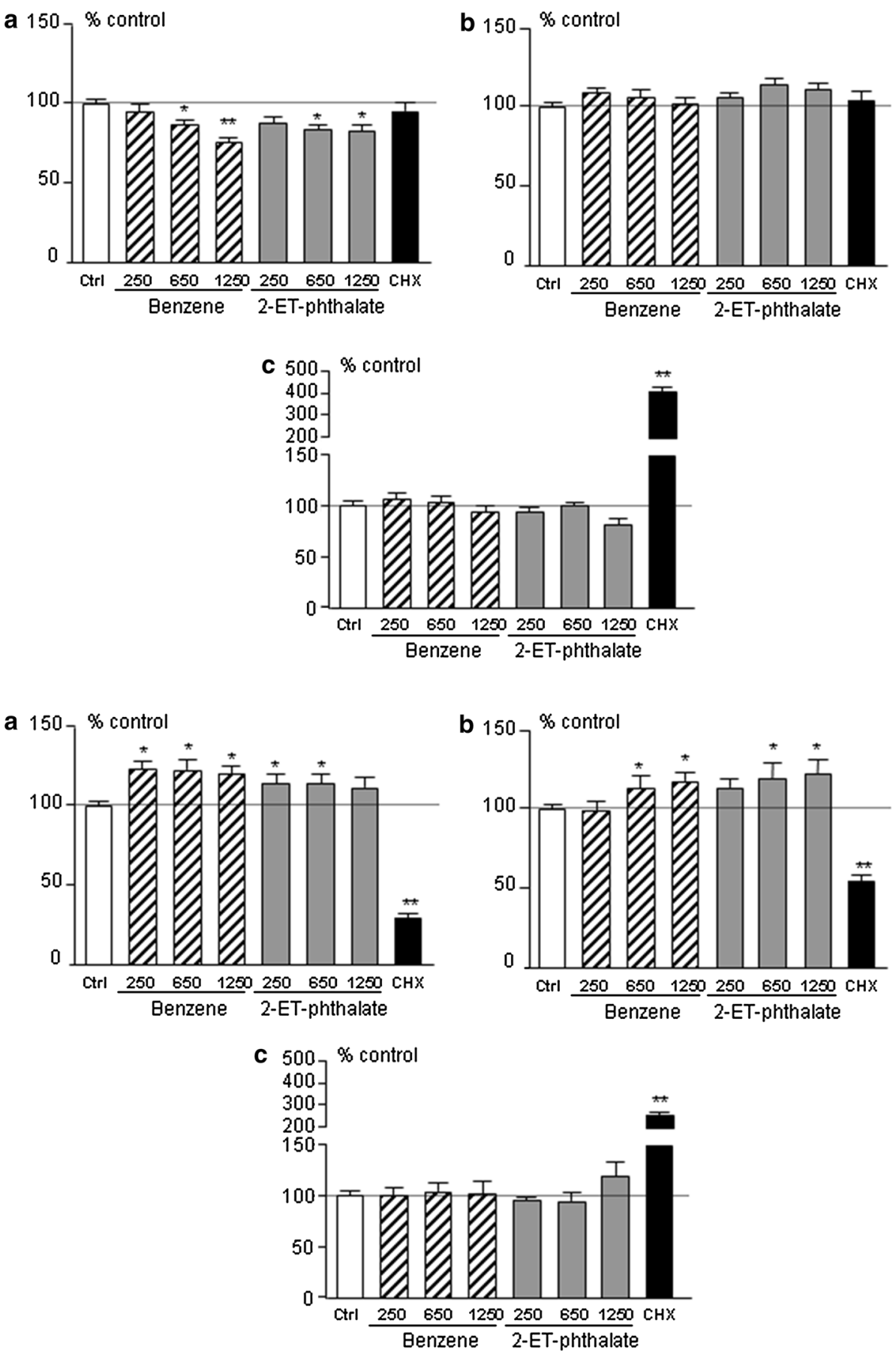

and release has been observed with toxaphene, bisphenol A, dioxin and other alkyl-phenols [37-40].

Our study shows for the first time that endocrine pollutants can stimulate proliferation in normal adult pituitary cells. Our finding is of particular relevance given that the abovementioned studies have been performed on tumoral pituitary cell lines, thus unsuitable to study the development of pituitary tumors. So far, only cadmium, a heavy metal with long half-life and estrogen-like activity, has been studied in the normal pituitary in vitro and increased cell growth was observed after 96-h incubation [36]. In this context, it has been reported that perinatal administration of endocrine disruptors is associated with increased incidence of pituitary tumors in grown rats [18] and, interestingly, that cats with acromegaly present higher plasma concentrations of halogenated contaminants, such as polychlorinated biphenyls, polybrominated diphenyl ethers and dichlorophenyl ethane, compared to non-acromegalic cats [41]. Altogether, it appears that the normal pituitary is indeed sensitive to the proliferative effect of endocrine contaminants. 


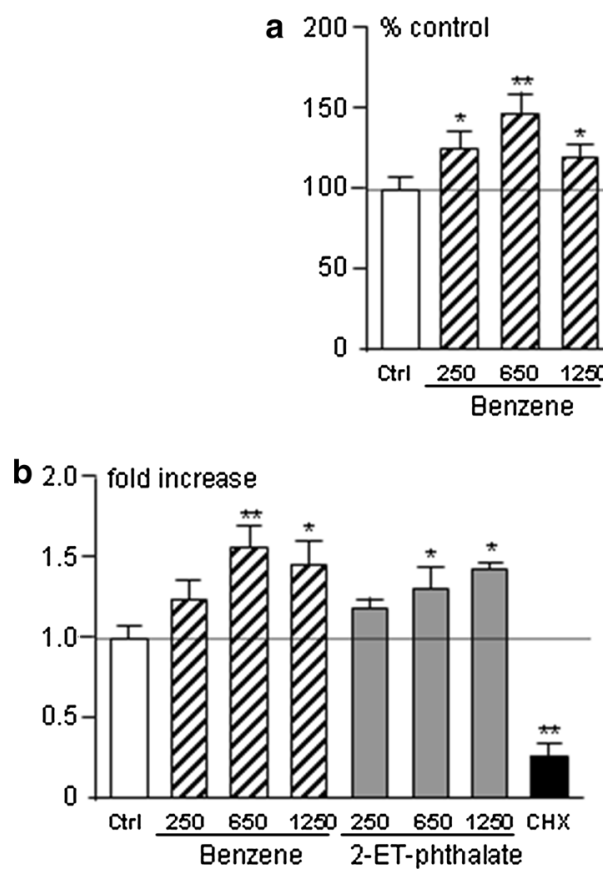

Fig. 3 Cell proliferation (a) and Ccndl (b) and Pttg1 expression (c) in rat anterior pituitary primary cultures. Cells were treated with 250, $650 \mathrm{pM}$ benzene (Ben, striped bars) or 2-ethyl-phthalate (2-ET, grey bars), $250 \mu \mathrm{g} / \mathrm{ml}$ of cycloheximide (CHX, black bar) in proliferation experiments and with $650,1250 \mathrm{pM}$ benzene (Ben, striped bars) or 2-ethyl-phthalate (2-ET, grey bars) for mRNA

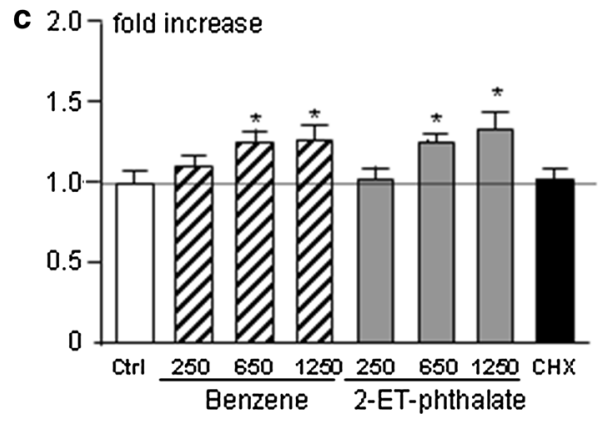

quantification experiments. Both experiments were carried out for 96 h. White bars represent control wells treated with plain medium (Ctrl). Data were normalized to control values and expressed as percentage of control in proliferation experiments and fold-increase in gene expression experiments; bars represent mean \pm SEM from three separate experiments
Fig. 4 Quantification of $A h R$ (a) and $A I P(\mathbf{b})$ expression in rat anterior pituitary primary cultures treated with 250,650 , $1250 \mathrm{pM}$ benzene (Ben, striped bars) or 2-ethyl-phthalate (2ET, grey bars), $250 \mu \mathrm{g} / \mathrm{ml}$ of cycloheximide (CHX, black bar) for 3, 24 and $96 \mathrm{~h}$. White bars represent control wells treated with plain medium (Ctrl). Expression data were analyzed as $2^{-\Delta \Delta \mathrm{Ct}}$ in three independent experiments and expressed as fold increase over control
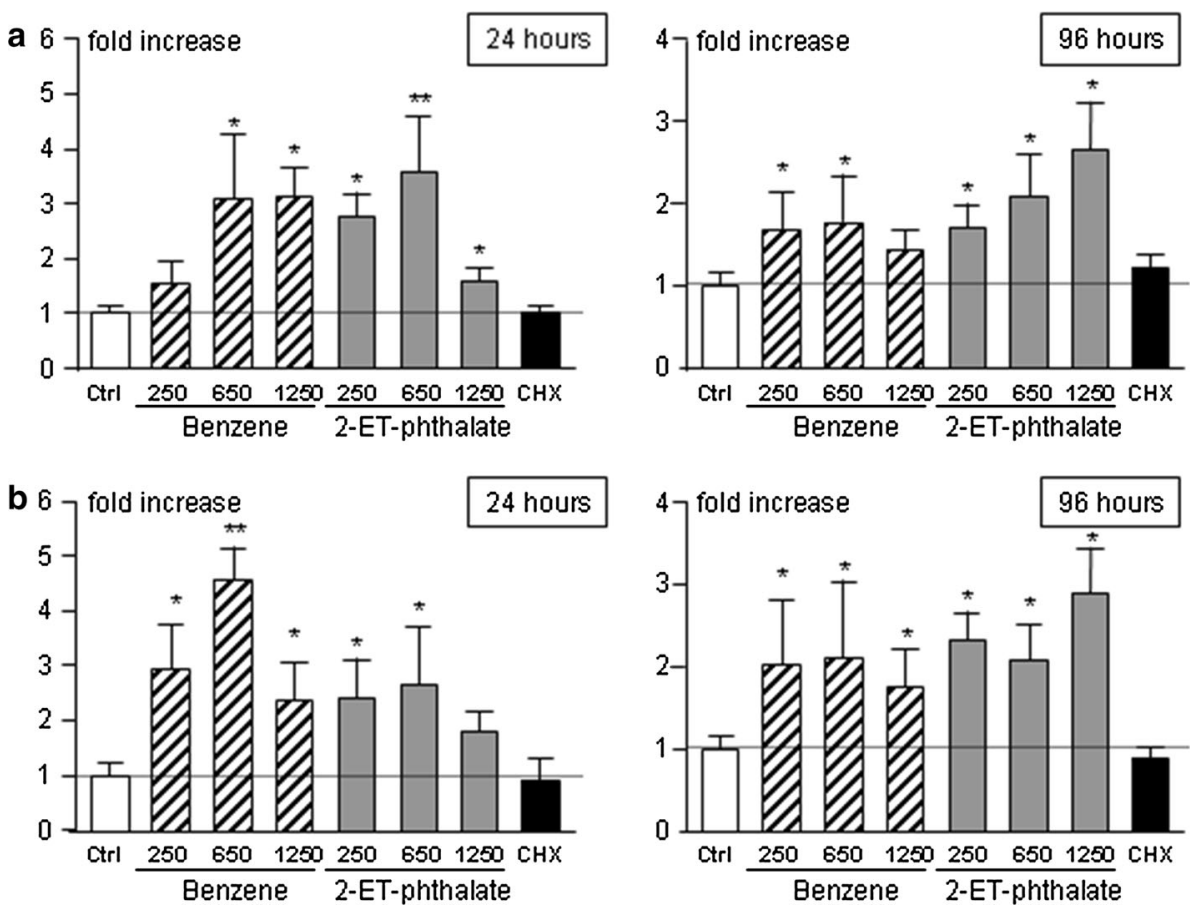

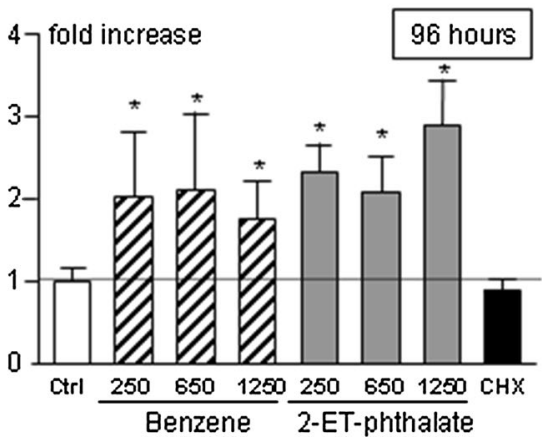

Endocrine disruptors were first identified as compounds with estrogenic potential [42] and, as such, act via the estrogen/androgen receptor pathway [43, 44]. Indeed, the estrogen receptor is involved also in stimulation of proliferation and transcription in pituitary cell lines [14, 36, 39, 45], mainly via the ERK pathway [16]. Current evidence demonstrates that disruptors call several additional pathways into play including the AhR-AIP-ARNT 
system [23]. AhR is a cytosolic transcription factor first identified through its dioxin-binding capacity and, indeed, mediates a variety of responses to toxic halogenated aromatic hydrocarbons [22]. AIP acts as chaperone to AhR and facilitates activation of AhR; in turn, activated AhR translocates into the nucleus, heterodimerizes with AhRnuclear translocator (ARNT) and acts upon target genes [46]. The role of this pathway in carcinogenesis is the focus of increasing interest [23] and, indeed, a link to pituitary tumorigenesis was recently detected as germline mutations in AIP were shown to predispose to development of pituitary adenomas [21]. Several studies followed upon this first report in an attempt to clarify the pathogenesis of AIPmutated pituitary tumors but the exact mechanism remains elusive [47, 48]. In fact, expression and cellular localization of AIP, AhR and ARNT appear variable with some tumors presenting low AIP, absent nuclear AhR staining and loss of ARNT expression, others increased AIP expression or nuclear AhR staining [49-51]. A most recent study in fibroblasts from patients with four different $A I P$ mutations showed that $A h R$ expression was unaffected but that AhR target genes, i.e. CYPIBl, AhR repressor $(A H R R)$, were either reduced or increased depending on the $A I P$ variant [52]. From a clinical viewpoint, patients carrying $A I P$ mutations are more often young, male and with large $\mathrm{GH}$ - or mixed $\mathrm{GH}$ - and prolactin-secreting tumors [48, 53, 54]. Interestingly, the $A h R$ gene itself appears to contribute to severity of acromegaly as polymorphisms and variants in $A h R$ have been associated with more aggressive disease $[55,56]$.

Altogether, it is clear that the AhR-AIP pathway is involved in pituitary tumorigenesis and our findings shed further light into this concept. We observed an increase in $A h R$ and $A I P$ expression during treatment with benzene and 2-ethyl-phthalate, which represents the first evidence for upregulation of $A h R / A I P$ gene expression in normal pituitaries in vitro. Data in pituitary cell lines showed that some AhR ligands, e.g. B-naphtoflavone, prothioconazole, reduce AhR expression [57] and function [24] while other AhR ligands, e.g. 2-methyl-4-chlorophenoxyacetic acid, taufluvalinate, stimulate AhR activity [24]. In contrast, dioxin, the main AhR ligand, failed to affect AhR expression in pituitary cells in vitro [58] and no changes in anterior pituitary $A h R$ expression up to 4 weeks after dioxin administration were observed in vivo [59]. As regards benzene and 2-ethyl-phthalate, both act via AhR in different cell models $[60,61]$ and our evidence now shows that these endocrine disruptors modulate the pituitary AhR/ AIP pathway.

Last, one word of comment on our research protocol. As mentioned above, our study evaluated the effects of two specific pollutants, benzene and 2-ethyl-phthalate, rather than a mixture of pollutants, as usually occurs for both routine and occupational exposure. Indeed, research strategies into the impact of endocrine disruptors encourage testing with a variety of chemicals at different dosages in distinct stages of development [62]. In order for this research to prove significant, however, there has to be some evidence on the effect of one or another pollutant in a given tissue. Our findings prove that benzene and 2-ethyl-phthalate stimulate proliferation in adult rat pituitary cells and provide the basis for further studies aimed at expanding upon our results, e.g. susceptibility in adult vs early life, effect of low-dose chemical mixtures, multigenerational studies in exposed areas [3].

Funding This work was supported by the Italian Ministry for Teaching, University and Research (PRIN 2010-2011 Grant Number 2010TYCL9B_004).

\section{Compliance with ethical standards}

Conflict of interest The Authors declare that there is no conflict of interest.

Open Access This article is distributed under the terms of the Creative Commons Attribution 4.0 International License (http://crea tivecommons.org/licenses/by/4.0/), which permits unrestricted use, distribution, and reproduction in any medium, provided you give appropriate credit to the original author(s) and the source, provide a link to the Creative Commons license, and indicate if changes were made.

\section{References}

1. Kabir ER, Rahman MS, Rahman I (2015) A review on endocrine disruptors and their possible impacts on human health. Environ Toxicol Pharmacol 40:241-258

2. Gore AC (2015) Neuroendocrine targets of endocrine disruptors. Hormones 9:16-27

3. Gore AC, Chappell VA, Fenton SE, Flaws JA, Nadal A, Prins GS, Toppari J, Zoeller RT (2015) EDC-2: the endocrine society's second scientific statement on endocrine-disrupting chemicals. Endocr Rev 36:E1-E150

4. Schug TT, Johnson AF, Birnbaum LS, Colborn T, Guillette LJ Jr, Crews DP, Collins T, Soto AM, Vom Saal FS, McLachlan JA, Sonnenschein C, Heindel JJ (2016) Minireview: endocrine disruptors: past lessons and future directions. Mol Endocrinol 30:833-847

5. Hampl R, Kubatova J, Starka L (2016) Steroids and endocrine disruptors-history, recent state of art and open questions. J Steroid Biochem Mol Biol 155:217-223

6. Saracci R, Kogevinas M, Bertazzi PA, Bueno de Mesquita BH, Coggon D, Green LM, Kauppinen T, L'Abbe KA, Littorin M, Lynge E (1991) Cancer mortality in workers exposed to chlorophenoxy herbicides and chlorophenols. Lancet 338:1027-1032

7. Rudel RA, Fenton SE, Ackerman JM, Euling SY, Makris SL (2011) Environmental exposures and mammary gland development: state of the science, public health implications, and research recommendations. Environ Health Perspect 119:1053-1061

8. Warner M, Mocarelli P, Samuels S, Needham L, Brambilla P, Eskenazi B (2011) Dioxin exposure and cancer risk in the Seveso Women's Health Study. Environ Health Perspect 119:1700-1705 
9. Hemminki K, Li X (2002) Cancer risks in second-generation immigrants to Sweden. Int J Cancer 99:229-237

10. Akthar FZ, Garabrant DH, Ketchum NS, Michalek JE (2004) Cancer in US Air Force veterans of the Vietnam war. J Occup Environ Med 46:123-136

11. Dairkee SH, Luciani-Torres MG, Moore DH, Goodson WH III (2013) Bisphenol-A-induced inactivation of the p53 axis underlying deregulation of proliferation kinetics, and cell death in nonmalignant human breast epithelial cells. Carcinogenesis 34:703-712

12. Mlynarcikova A, Macho L, Fickova M (2013) Bisphenol A alone or in combination with estradiol modulates cell cycle- and apoptosis-related proteins and genes in MCF7 cells. Endocr Regul 47:189-199

13. Kang NH, Hwang KA, Lee HR, Choi DW, Choi KC (2013) Resveratrol regulates the cell viability promoted by 17betaestradiol or bisphenol A via down-regulation of the cross-talk between estrogen receptor alpha and insulin growth factor-1 receptor in BG-1 ovarian cancer cells. Food Chem Toxicol 59:373-379

14. Maruyama S, Fujimoto N, Yin H, Ito A (1999) Growth stimulation of a rat pituitary cell line MtT/E-2 by environmental estrogens in vitro and in vivo. Endocr J 46:513-520

15. Fujimoto N (2003) Effects of environmental estrogenic compounds on growth of a transplanted estrogen responsive pituitary tumor cell line in rats. Food Chem Toxicol 41:1711-1717

16. Vinas R, Watson CS (2013) Mixtures of xenoestrogens disrupt estradiol-induced non-genomic signaling and downstream functions in pituitary cells. Environ Health 12:26-36

17. Cossette LJ, Gaumond I, Martinoli MG (2002) Combined effect of xenoestrogens and growth factors in two estrogen-responsive cell lines. Endocrine 18:303-308

18. Isling LK, Boberg J, Jacobsen PR, Mandrup KR, Axelstad M, Christiansen S, Vinggaard AM, Taxvig C, Kortenkamp A, Hass U (2014) Late-life effects on rat reproductive system after developmental exposure to mixtures of endocrine disrupters. Reproduction 147:465-476

19. Cannavò S, Ferraù F, Ragonese M, Curtò L, Torre ML, Magistri M, Marchese A, Alibrandi A, Trimarchi F (2010) Increased prevalence of acromegaly in a highly polluted area. Eur $\mathbf{J}$ Endocrinol 163:509-513

20. Pesatori AC, Baccarelli A, Consonni D, Lania A, Beck-Peccoz P, Bertazzi PA, Spada A (2008) Aryl hydrocarbon receptor-interacting protein and pituitary adenomas: a population-based study on subjects exposed to dioxin after the Seveso, Italy, accident. Eur J Endocrinol 159:699-703

21. Vierimaa O, Georgitsi M, Lehtonen R, Vahteristo P, Kokko A, Raitila A, Tuppurainen K, Ebeling TM, Salmela PI, Paschke R, Gündogdu S, De Menis E, Mäkinen MJ, Launonen V, Karhu A, Aaltonen LA (2006) Pituitary adenoma predisposition caused by germline mutations in the AIP gene. Science 312:1228-1230

22. Poland A, Knutson J, Glover E (1985) Studies on the mechanism of action of halogenated aromatic hydrocarbons. Clin Physiol Biochem 3:147-154

23. Safe S (2001) Molecular biology of the Ah receptor and its role in carcinogenesis. Toxicol Lett 120:1-7

24. Ghisari M, Long M, Tabbo A, Bonefeld-Jorgensen EC (2015) Effects of currently used pesticides and their mixtures on the function of thyroid hormone and aryl hydrocarbon receptor in cell culture. Toxicol Appl Pharmacol 284:292-303

25. Tran C, Richmond O, Aaron L, Powell JB (2013) Inhibition of constitutive aryl hydrocarbon receptor (AhR) signaling attenuates androgen independent signaling and growth in (C4-2) prostate cancer cells. Biochem Pharmacol 85:753-762

26. Pecori Giraldi F, Cavagnini F (1998) Corticotropin-releasing hormone is produced by rat corticotropes and modulates ACTH secretion in a paracrine/autocrine fashion. $\mathrm{J}$ Clin Invest 101:2478-2484

27. Pecori Giraldi F, Pesce S, Maroni P, Pagliardini L, Lasio G, Losa M, Cavagnini F (2010) Inhibitory effect of preproTRH(178-199) on ACTH secretion by human corticotrope tumours. J Neuroendocrinol 22:294-300

28. Nagami K, Kawashima Y, Kuno H, Kemi M, Matsumoto $\mathrm{H}$ (2002) In vitro cytotoxicity assay to screen compounds for apoptosis-inducing potential on lymphocytes and neutrophils. J Toxicol Sci 27:191-203

29. Rodrigues RM, Bouhifd M, Bories G, Sacco MG, Gribaldo L, Fabbri M, Coecke S, Whelan MP (2013) Assessment of an automated in vitro basal cytotoxicity test system based on metabolically-competent cells. Toxicol In Vitro 27:760-767

30. Heaney AP, Melmed S (1999) Pituitary tumour transforming gene: a novel factor in pituitary tumour formation. Bailliere's Clin Endocrinol Metab 13:367-380

31. Maqbool F, Mostafalou S, Bahadar H, Abdollahi M (2016) Review of endocrine disorders associated with environmental toxicants and possible involved mechanisms. Life Sci 145:265-273

32. Penaglotidou E, Zerva S, Mitsiou DJ, Alexis MN, Kitraki E (2014) Perinatal exposure to low-dose bisphenol A affects the neuroendocrine stress response. J Endocrinol 220:207-218

33. Murray TJ, Maffini MV, Ucci AA, Sonnenschein C, Soto AM (2007) Induction of mammary gland ductal hyperplasias and carcinoma in situ following fetal bisphenol A exposure. Reprod Toxicol 23:383-390

34. Prins GS, Birch L, Tang WY, Ho SM (2007) Developmental estrogen exposures predispose to prostate carcinogenesis with aging. Reprod Toxicol 23:374-382

35. Aflorei ED, Korbonits M (2014) Epidemiology and etiopathogenesis of pituitary adenomas. J Neurooncol 117:379-394

36. Ronchetti SA, Miler EA, Duvilanski BH, Cabilla JP (2013) Cadmium mimics estrogen-driven cell proliferation and prolactin secretion from anterior pituitary cells. PLoS ONE 8:e81101e81113

37. Steinmetz R, Brown NG, Allen DL, Bigsby RM, Ben JN (1997) The environmental estrogen bisphenol A stimulates prolactin release in vitro and in vivo. Endocrinology 138:1780-1786

38. Graham M, Cossette L, Gelinas S, Martinoli MG (2003) In vitro modulation of prolactin mRNA by toxaphene and $3,3^{\prime}, 4,4^{\prime}$-tetrachlorobiphenyl. Environ Res 92:207-212

39. Dang VH, Nguyen TH, Lee GS, Choi KC, Jeung EB (2009) In vitro exposure to xenoestrogens induces growth hormone transcription and release vie estrogen-receptor dependent pathways in rat pituitary GH3 cells. Steroids 74:707-714

40. Elango A, Shepherd B, Chen T (2006) Effects of endocrine disrupters on the expression of growth hormone and prolactin mRNA in the rainbow trout pituitary. Gen Comp Endocrinol 145:116-127

41. Dirtu AC, Niessen SJM, Jorens PG, Covaci A (2013) Organohalogenated contaminants in domestic cats' plasma in relation to spontaneous acromegaly and type 2 diabetes mellitus: a clue for endocrine disruption in humans? Environ Int 57-58:60-67

42. Feldman D, Krishnan A (1995) Estrogens in unexpected places: possible implications for researchers and consumers. Environ Health Perspect 103(Suppl 7):129-133

43. Kiyama R, Wada-Kiyama Y (2015) Estrogenic endocrine disruptors: molecular mechanisms of action. Environ Int 83:11-40

44. Kumar N, Sharan S, Srivastava S, Roy P (2014) Assessment of estrogenic potential of diethyl phthalate in female reproductive system involving both genomic and non-genomic actions. Reprod Toxicol 49:12-26

45. Dang VH, Nguyen TH, Choi KC, Jeung EB (2007) A calciumbinding protein, Calbindin-D9k, is regulated through an estrogen- 
receptor-mediated mechanism following xenoestrogen exposure in the GH3 cell line. Toxicol Sci 92:408-415

46. Mulero-Navarro S, Fernandez-Salguero PM (2016) New trends in aryl hydrocarbon receptor biology. Front Cell Dev Biol 4:45-59

47. Trivellin G, Korbonits M (2011) AIP and its interacting partners. J Endocrinol 210:137-155

48. Beckers A, Aaltonen LA, Daly AF, Karhu A (2013) Familial isolated pituitary adenomas (FIPA) and the pituitary adenoma predisposition due to mutations in the aryl hydrocarbon receptor interacting protein (AIP) gene. Endocr Rev 34:239-277

49. Jaffrain-Rea ML, Angelini M, Gargano D, Tichomirowa MA, Daly AF, Vanbellinghen JF, D'Innocenzo E, Barlier A, Giangaspero F, Esposito V, Ventura L, Arcella A, Theodoropoulou M, Naves LA, Fajardo C, Zacharieva S, Rohmer V, Brue T, Gulino A, Cantore G, Alesse E, Beckers A (2009) Expression of aryl hydrocarbon receptor (AHR) and AHR-interacting protein in pituitary adenomas: pathological and clinical implications. Endocr Relat Cancer 16:1029-1043

50. Heliövaara E, Raitila A, Launonen V, Paetau A, Arola J, Lehtonen H, Sane T, Weil RJ, Vierimaa O, Salmela P, Tuppurainen K, Mäkinen M, Aaltonen LA, Karhu A (2009) The expression of $A I P$-related molecules in elucidation of cellular pathways in pituitary adenomas. Am J Pathol 175:2501-2507

51. Hernandez-Ramirez LC, Martucci F, Morgan RM, Trivellin G, Tilley D, Ramos-Guajardo N, Iacovazzo D, D'Acquisto F, Prodromou C, Korbonits M (2016) Rapid proteasomal degradation of mutant proteins is the primary mechanism leading to tumorigenesis in patients with missense AIP mutations. J Clin Endocrinol Metab 101:3144-3154

52. Lecoq AL, Viengchareun S, Hage M, Bouligand J, Young J, Boutron A, Zizzari P, Lombes M, Chanson P, Kamenicky P (2016) AIP mutations impair AhR signaling in pituitary adenoma patients fibroblasts and in GH3 cells. Endocr Relat Cancer 23:433-443

53. Cazabat L, Guillaud-Bataille M, Bertherat J, Raffin-Sanson ML (2009) Mutations of the gene for the aryl hydrocarbon receptorinteracting protein in pituitary adenomas. Horm Res 71:132-141
54. Martucci F, Trivellin G, Korbonits M (2012) Familial isolated pituitary adenomas: an emerging clinical entity. J Endocrinol Invest 35:1003-1014

55. Cannavò S, Ferrau F, Ragonese M, Romeo PD, Torre ML, Puglisi S, De Menis E, Arnaldi G, Salpietro C, Cotta OR, Albani A, Ruggeri RM, Trimarchi F (2014) Increased frequency of the rs2066853 variant of aryl hydrocarbon receptor gene in patients with acromegaly. Clin Endocrinol 81:249-253

56. Cannavò S, Ragonese M, Puglisi S, Romeo PD, Torre ML, Alibrandi A, Scaroni C, Occhi G, Ceccato F, Regazzo D, De Menis E, Sartorato P, Arnaldi G, Trementino L, Trimarchi F, Ferrau F (2016) Acromegaly is more severe in patients with $A H R$ or AIP gene variants living in highly polluted areas. J Clin Endocrinol Metab 101:1872-1879

57. Moran TB, Brannick KE, Raetzman LT (2012) Aryl-hydrocarbon receptor activity modulates prolactin expression in the pituitary. Toxicol Appl Pharmacol 265:139-145

58. Huang P, Ceccatelli S, Håkansson H, Grandison L, Rannung A (2002) Constitutive and TCDD-induced expression of Ah receptor-responsive genes in the pituitary. NeuroToxicology 23:783-793

59. Huang $\mathrm{P}$, Rannung $\mathrm{A}$, Ahlbom E, Håkansson $\mathrm{H}$, Ceccatelli $\mathrm{S}$ (2000) Effect of 2,3,7,8-tetrachlorodibenzo- $p$-dioxin on the expression of cytochrome $\mathrm{P} 450$ 1A1, the aryl hydrocarbon receptor, and the aryl hydrocarbon receptor nuclear translocator in rat brain and pituitary. Toxicol Appl Pharmacol 169:159-167

60. Mankidy R, Wiseman S, Ma H, Giesy JP (2013) Biological impact of phthalates. Toxicol Lett 217:50-58

61. Yoon BI, Hirabayashi Y, Kawasaki Y, Kodama Y, Kaneko T, Kanno J, Kim DY, Fujii-Kuriyama Y, Inoue T (2002) Aryl hydrocarbon receptor mediates benzene-induced hematotoxicity. Toxicol Sci 70:150-156

62. Gore AC, Crews D, Doan LL, La Merril M, Patisaul H, Zota A (2014) Introduction to endocrine disrupting chemicals (EDC). A guide for public interest organizations and policy-makers. The Endocrine Society and IPEN, pp 1-69. http://ipen.org/documents/ introduction-endocrine-disrupting-chemicals-edcs 